\title{
The Effect of Leadership Style on Employee Commitment in the Mining Sector in Zimbabwe
}

\author{
Munyaradzi Chikove' ${ }^{1}$, Alphonce Shiri ${ }^{2}$ \\ ${ }^{1}$ Zimbabwe Open University, Harare, Zimbabwe \\ ${ }^{2}$ Midlands State University, Gweru, Zimbabwe \\ Email: mchikove4@gmail.com, alphshiri@gmail.com
}

How to cite this paper: Chikove, M., \& Shiri, A. (2021). The Effect of Leadership Style on Employee Commitment in the Mining Sector in Zimbabwe. American Journal of Industrial and Business Management, 11, 1023-1035.

https://doi.org/10.4236/ajibm.2021.1110062

Received: August 4, 2021

Accepted: October 15, 2021

Published: October 18, 2021

Copyright (อ 2021 by author(s) and Scientific Research Publishing Inc. This work is licensed under the Creative Commons Attribution International License (CC BY 4.0).

http://creativecommons.org/licenses/by/4.0/

\begin{abstract}
The purpose of this study was to establish the effect of leadership style on employee commitment in the mining sector in Zimbabwe. The mining industry in Zimbabwe has been extensively affected by the loss of key personnel in key areas such as engineering, metallurgy and geology among others. The loss of such vital employees in the mining sector has had a negative impact on output and consequently loss of the much-needed revenue to the Zimbabwean economy. It is against this background that there was a need to establish the effect of leadership style on employee commitment in an endeavour to enhance job satisfaction. A quantitative approach was adopted in which convenience sampling was employed. The main findings were that charismatic and inspirational leadership style has moderate to strong positive relationship with subordinate affective commitment to the organisation. Inspirational motivation had a moderate positive correlation with affective commitment significant at $(\mathrm{r}=0.46 ; p<0.05)$ and Intellectual stimulation was found to have a strong correlation with affective commitment, significant at $(\mathrm{r}=0.67 ; p<$ 0.05). Laissez faire leadership style displayed a very weak negative correlation between management by exception active with affective commitment, significant at $(\mathrm{r}=-0.012 ; p<0.05)$. This study recommends that managers in the Zimbabwe mining sector should strive to use inspirational approaches in leading and involve employees in decision-making so as to raise the standards of efficiency and effectiveness of an organization and increase follower commitment.
\end{abstract}

\section{Keywords}

Motivation, Job Satisfaction, Normative Commitment, Continuance Commitment, Affective Commitment 


\section{Introduction and Background}

The purpose of this study is to discover the effect of leadership style on employee commitment in the mining sector in zimbabwe. This was prompted by the realisation that the mining industry in Zimbabwe continues to lose skilled personnel and this has retarded the country's economic growth (CMZ, 2017). It is noteworthy that skilled employees are lost and this has tremendously affected productivity in the mining sector, ultimately leading to a failure to achieve organisational objectives. In spite of the mining industry in Zimbabwe is regarded as the cornerstone of economic growth, it has been hemorrhaged by skills flight (Segula, 2015). The mining industry remains the epicenter for economic recovery in Zimbabwe. For example, according to several pronouncements by the Chamber of Mines of Zimbabwe (CMZ, 2015, 2016, 2017, 2018), the Zimbabwean mining sector has been hemorrhaged by skills fight. For this reason, there is an emphasis on the managers embracing the appropriate leadership style in an endeavour to guard against the loss of key personnel. Employees are key assets to any organisation and these employees should be effectively motivated (Robbins \& Coulter, 2012). However, in spite of this emphasis on the promotion of strategies for motivating personnel by several mining companies in Zimbabwe, the sector has been hamstrung by the shortage of skilled labour force, thereby failing to meet the targeted economic growth rates.

Employee motivation is the panacea for achieving goals at any organisation (Lahkar Das \& Baruah, 2013). It can therefore be claimed that the labour force is the life-blood of any company hence the management should use the appropriate leadership style among other strategies to lure and keep them at their organisations. The management of Zimbabwean mining companies should endeavour to use a plethora of motivational factors and strategies at their organisation so as to guard against high labour turnover (Robbins \& Coulter, 2012). It is essential to note that employees are dynamic resources of any organisation who need to be extensively motivated. It is prudent for the management of firms to identify the causes of skills fight so as to find out what really engenders employee loyalty, high performance levels as well as concerted engagement (Hazriyanto \& Ibrahim, 2019). Fundamentally, this mechanism ensures the management understands why key employees may desire to stay with an organization for a long period. It is equally important to understand why at times employees may decide to search for alternative opportunities elsewhere. According to the York (2017), effective motivation of employees leads to increased commitment and hence the potential to meet organisational objectives. It follows therefore that improved attraction as well as retention of key personnel through motivation strategies enhances productivity in the Zimbabwean mining sector and promotes economic growth. The loss of key employees who wield critical skills has negatively affected productivity and revenue generation for the Zimbabwean economy (CMZ, 2016). Considering that mining organisations have failed to guard against the loss of key and talented workforce in Zimbabwe's mining industry, it is im- 
perative to discover the effect of the leadership styles employed by the management on employee commitment at their organisations.

\section{Statement of the Problem}

According to CMZ $(2013,2015,2016)$ the mining sector in Zimbabwe is currently bedeviled by a scarcity of talented and experienced employees. This implies that production in the mining sector has gone down because of a failure to effectively motivate personnel by company executives. Chamber of Mines of Zimbabwe (2017) argue that formal employment in 2012 in the mining sector stood at 45,800 and significantly declined by $45 \%$ over the years to 25,000 in 2016 . Thus, failure to effectively motivate employees triggers high labour turnover. According to the World Bank (2009) Zimbabwe strongly depended on asbestos as it was the country's principal mineral in terms of value and output between 1965 and 1978. It is worth noting that production of asbestos in 1974 peaked at 281,000 tons but in 2012 production stood at 29.5 tons (CMZ, 2015). The decline in productivity could be attributed to the failure by mining companies to retain key personnel among other reasons. According to $\operatorname{CMZ}(2015,2016)$ coal output in 2003 was close to 3million tons and in 2012 the output was 1.75 million tons; gold's contribution to total mineral exports in 2003 was 57, 3\% and in 2012 the contribution stood at $26,9 \%$. This clearly reveals that the Zimbabwean mining industry has been plagued by the loss of personnel, making attraction and retention strategies important facets in harnessing skilled employees. Nickel's contribution to the total mineral exports by 2003 stood at $15.1 \%$ and in 2012 its contribution was $0.7 \%$ (CMZ, 2016). This implies that if employees feel that they are not being well-remunerated they opt to leave and production falls to alarming levels hence the downward trend in terms of productivity can be attributed to the skills flight.

CMZ (2018) affirms that productivity in the Zimbabwe's mining industry has dwindled due to the crippling skills shortage. This has adverse effects on productivity. CMZ (2013) asserts that local universities in Zimbabwe have since become producers of high-level skills for other countries as these flock there upon attaining the qualification. This implies that the Zimbabwean mining sector has been severely affected by the loss of skilled personnel. This bleak scenario was presented at the Zimbabwe Chamber of Mines' $70^{\text {th }}$ Annual General Meeting held late last month (CMZ, 2018). The loss of skilled personnel is a national catastrophe which needs urgent attention. In a statement, the CMZ (2015) said the situation regarding the skills fight in the mining sector is dire such that the Chamber was obliged to consider in detail the impact of the brain drain, test the appropriateness of the current interventions dealing with the situation, and above all determine macro assistance required to halt or reverse the flight of skills. According to CMZ (2015), the emigration of technically competent and experienced persons is common knowledge and is now of great concern for the maintenance of mining and metallurgical operations, for the replacement of ex- 
hausted deposits, and for the expansion of others. Most of the vacancies are in the technical disciplines by training institutions, including the University of Zimbabwe, the Zimbabwe School of Mines and the polytechnics that are also under stress and certain key disciplines that cannot be taught or examined adequately because of a shortage of qualified lecturers or examiners. This loss of skilled personnel in the mining sector has also been worsened by the loss of personnel at the institutions of higher learning. Essentially, the attraction and retention of skilled employees becomes crucial for the mining organisations to meet their set objectives.

According to CMZ (2016), the Zimbabwe's mining industry has been plagued by skills flight due to poor working condition as well as meagre salaries in the face of skyrocketing prices of goods and services. Poor motivation of employees has negative consequences on employee morale hence they quest for alternatives. The majority of workers migrated to neighboring countries in the SADC region (CMZ, 2018). The base line is that employees have no option except to go where they are better motivated. The CMZ (2016) affirms that mining companies in Zimbabwe are operating way below the expected levels. It can therefore be inferred that production in the mining sector has gone down due to the failure to attract and retain skilled personnel among other reasons.

Armstrong (2006) admits that high employee turnover has detrimental effects to organisations in terms of productivity. Therefore, employee retention through effective motivation is vital to an organization's success. The significance of implementing an employee retention programme lies in that it is an effective way of ensuring key employees workers remain employed hence enabling the achievement of organisational objectives (Kshirsagar \& Waghale, 2014). Managers should use intrinsic and extrinsic factors to lure and retain skilled employees. According to Horwitz and Budhwar (2016) employees are the organization's most valuable asset but if the human resources department is not doing its part to make them feel valued, then they will leave the organisation. Top talent is in high demand in this increasingly competitive business world. Thus, mining organisations in Zimbabwe should strive to keep their employees at the work place through effective motivation.

\section{Literature Review}

This section reviews literature and contextualizes the problem in terms of how commitment and job satisfaction is defined in the workplace, specifically the mining sector.

\subsection{Commitment}

Organisational commitment is the psychological attachment to one's job and the workplace. Commitment may be described as the willingness to stay with an organisation in face of challenges (Meyer \& Allen, 2004). It is the strength of an individual's identification with the organisation (Steyrer, Schffinger, \& Lang, 
2008). In other words, organisational commitment is the orientation that an individuals has towards his or her organisational values and goals which drives them to maintain consistency in activities that promotes those values (Robbins, Judge, Ordendaal, \& Roodt, 2010). While organisational commitment may be viewed as the attitude and dedication to an organisation, one may ask what really constitute the dispositional attributes of organisational commitment. Mowday, Porter and Steers in Nyengane (2007) identified attributes of organisational commitment as:

- a strong belief in and acceptance of the organisation's goals and values';

- a willingness to exert a considerable effort on behalf of the organization;

- a strong intent or desire to remain with the organization.

These attributes therefore means that there is strong goal and value congruence between the employee and the organisation. Nyengane (2007) asserts that organisational commitment results in increased work performance which in turn enhances organisational performance. Meyer and Allen (2004) propose that commitment consists of three elements which are affective commitment, normative commitment and continuance commitment as shown in Figure 1.

Affective commitment as shown in Figure 1, may be attributable to the emotional attachment that an employee has to the organisation. A strong emotional connection is developed over time as the employee finds the job to be intrinsically rewarding. Brotheridge, Lee, Ozcelik, Langton and Aldrich (2008) assert that affective commitment leads to hard work and increased work performance that in turn enhances organisational performance.

Continuance commitment is the commitment that is induced by economic benefits accrued over time by continued association with the organisation. This type of commitment to the organisation may also be driven by fear of economic loss due to departure from the organisation (Meyer \& Allen, 2004). Age and work experience may therefore be a significant factor that drives continuance

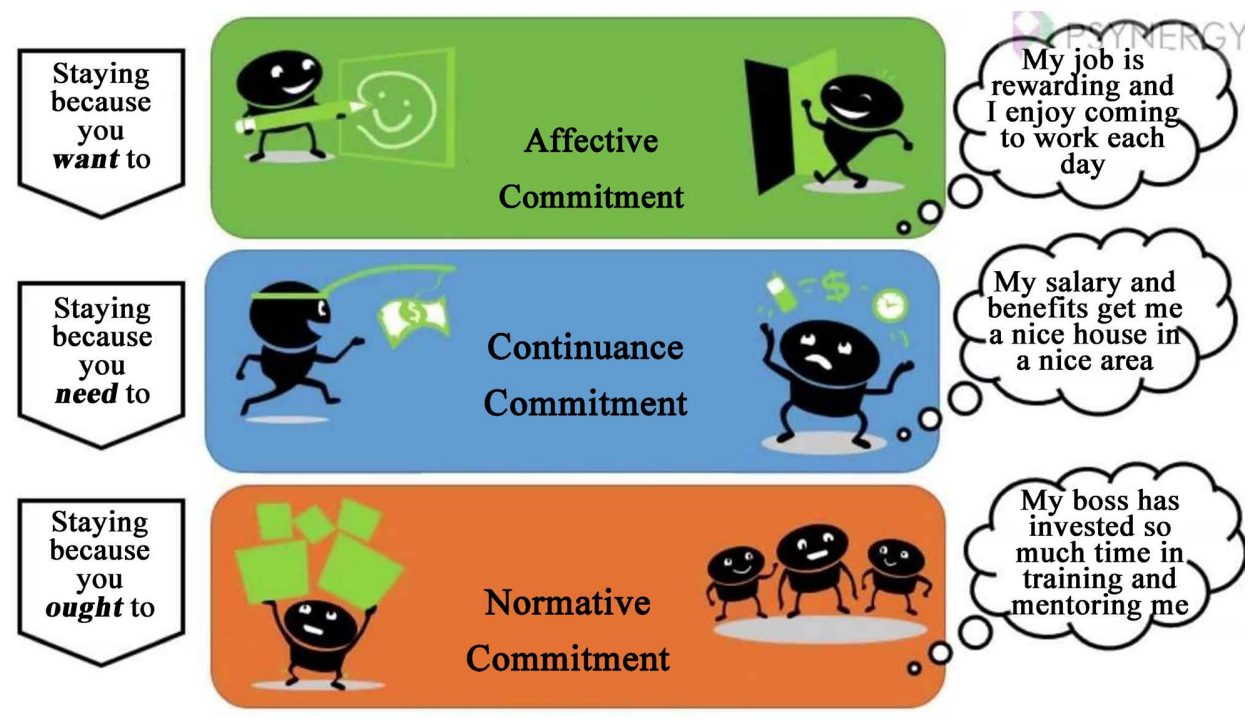

Figure 1. Dimensions of Commitment Source: Meyer and Allen (2004). 
commitment (Steyrer et al., 2008).

Normative commitment as shown in Figure 1, is driven by obligatory feelings towards one's organisation. An employee would feel indebted to is or her organisation as a result of the benefits received over time such as staff skills development and training. Normative commitment therefore means that an employee is flexible and ready to accept any challenging situations (Brotheridge et al., 2008) as they arise in the organisation including job reassignments caused by organisational restructuring.

The concept of work commitment was adopted in this study to find out how leadership behaviours may induce employee feelings towards the organisation and whether the leader is able to influence commitment under challenging work environments as found in the mining sector in Zimbabwe. Below, we shall discuss contemporary leadership styles and theory and how it impacts on employee commitment.

\subsection{Leadership Style}

This study tested contemporary leadership styles, namely: transformational, transactional and laissez-faire leadership styles and how they influence employee commitment in the mining sector in Zimbabwe. Burns (1978) coined the terms and distinctions between transformational and transactional leadership whose dimensions were identified and explained by Bass (1985). These leadership dimensions are described below.

Transformational leadership style is characterized by behaviours such as idealized influence, inspirational motivation, intellectual stimulation and individual consideration. Idealized influence is leadership behaviour that upholds high standards of moral and ethical conduct. This results in employee high personal regard for the leader and ignites feelings loyalty toward the leader. Inspirational motivation is when the leader inspires followers through the articulation of a vision. Leadership behaviours include the use of persuasive language that influences employees to adopt the leader's vision as if it's their own. Using, intellectual stimulation te leader challenges his or her subordinates to think outside the box and see problems as opportunities to do better. Employees are challenged to look at new and different ways of accomplishing tasks. Individual consideration is leadership behaviour that values the unique contribution of each employee. The leader takes his or her time to coach subordinates and provide mentorship. Individual consideration behaviours induce feelings of belonging in employee.

Transactional leadership style is characterised by contingent reward, management by exception active and management by exception passive behaviours. Contingent reward describes leadership behaviours that used rewards (tangible and intangible) to persuade subordinates to work hard and meet expected standards of performance. The leader clarifies what constitutes rewards for meeting expected goals and standards of performance. Management by exception active is transactional leadership behaviour that is characterised by actively monitoring 
subordinates' performance and focusing on mistakes and deviations from expected performance standards. The leader takes corrective action by rebuking or giving a warning whenever an employee fails to meet performance standards or makes a mistake. Management by exception passive is transactional leadership behaviour that is passive in which the leader only gets involved when problems become serious. The manager directs subordinate activity through an "if it ain't broken, don't fix it" approach.

Laissez-faire leadership style is when the leader completely avoids his or her responsibilities. The leader avoids getting involved in important issues as they arise and delays responding to urgent situations. The leader avoids clarifying work performance expectations or setting standards for employees to follow.

\subsection{Leadership Style and Employee Commitment}

This study sought to unpack the impact of contemporary leadership styles on employees' willingness to stay with the organisation. A leader may exhibit an array of behaviours that have different effects on subordinates' level of commitment to the organisation. Empirical evidence seem to suggest that by and large, transformational leadership positively influences employee commitment while transactional leadership impact varies from moderate positive influence to no significant relationship. Emery and Bakker (2007) found that the charisma dimension of transformational leadership significantly correlated with employee organisational commitment in a food store, at $(\mathrm{r}=0.426 ; p<0.01)$. The same study also found that intellectual stimulation and individual consideration had significant $(p<0.01)$ correlation to employee commitment with a moderate $\mathrm{r}=$ 0.376 and 0.371 , respectively. Emery and Bakker (2007) further found that contingent reward was the only dimension of transactional leadership that had a significant positive $p<0.01$ correlation with employee commitment with a low $\mathrm{r}$ $=0.244$. Management by exception passive had a significant $p<0.05$ correlation with a negative $r=-0.53$. Management by exception passive had no significant relationship with employee commitment. These results confirmed earlier research by Lee (2005), who found that transformational leadership positively correlated to employee commitment and transactional leadership had no significant relationship with employee commitment. Hayward, Goss and Tolmay (2004) also support that there is no significant relationship between transactional leadership and employee commitment. These studies were conducted under different settings than the mining sector and the objective of this study was to find out how the different leadership styles relate to employee commitment in the mining sector in Zimbabwe and contribute towards better management of mining employees and better understanding of the effects of leadership behaviours.

\section{Methodology}

This article basically employed the quantitative research method. Edmonds, \& Kennedy, (2012) affirm that it is a type of educational research in which the re- 
searcher decides what to study; asks specific, narrow questions; collects quantifiable data from participants; analyzes these numbers using statistics; and conducts the inquiry in an unbiased, objective manner. Marshal and Rossman (2016) list the characteristics of quantitative research as:

- An emphasis on collecting and analyzing information in the form of numbers;

- An emphasis on collecting scores that measure distinct attributes of individuals and organizations;

- An emphasis on the procedures of comparing groups or relating factors about individuals or groups in experiments, correlational studies, and surveys.

\subsection{Population}

Creswell (2013) describe population as the universe of people, places or things to be investigated. In other words, the population includes all objects of interest. The population in this study was two hundred and twenty (220) employees in selected gold mines existing in Mberengwa and Zvishavane district. The target population was derived from the population. This refers to people who would directly be involved in the research. From a population of about two $220 \mathrm{em}$ ployees in the gold mineral sector this study only targeted 140 employees.

\subsection{Sampling Techniques}

A convenience sampling approach was adopted for the study. Participants were randomly chosen ranging from low level employees to senior managers at company. The sample consisted of 140 employees. This sample size is in line with Krejcie and Morgan (1970).

\subsection{Research Instrument and Data Collection}

The researchers used a questionnaire on a 5 point Likert scale to collect data. The questionnaires were distributed to all the 140 respondents but 113 questionnaires were returned by shaft workers in the gold mining sector in Zvishavane and Mberengwa Districts. The researcher monitored the respondents complete the questionnaires to ensure that they did not discuss and hence influence each other's response. The need to answer questions independently was emphasized. To enhance the freedom of response the respondents were instructed not to write their names on the questionnaires. The recovered questionnaires were 113 , constituting an $80 \%$ response rate.

\subsection{Measures}

This study adopted a Meyer and Allen (1997) scale for measuring affective, continuance and normative commitment. However continuance and normative commitment measurement items were excluded from this study because it focused on testing the effects of leadership behaviours on subordinates' desire to stay with the organisation in terms of affective commitment.

Leadership behaviours were tested using Bass and Avolio's (1997) multifactor 
leadership questionnaire (MLQ). 28 items from the scale were tested against employee commitment measure. The measurement items for laissez faire leadership style were dropped because it was determined from the survey that employees agreed that such laissez faire leadership behaviours were rare in the mining sector in Zimbabwe with a mean and standard deviation of $\mathrm{M}=1.52$ and $\mathrm{SD}=0.24$.

\section{Results and Discussion}

The internal consistency and reliability of measurements was tested using Cronbach's alpha coefficient. The results of the Cronbach's coefficient alpha are shown in Table 1. Hair et al. (2014) suggest that a value of .70 and above is acceptable for internal consistency.

Table 1. Results of the cronbach's alpha coefficient.

\begin{tabular}{ccc}
\hline Measures & Number of items & Cronbach's Coefficient Alpha \\
\hline Individual consideration & 4 & 0.84 \\
Inspirational motivation & 4 & 0.72 \\
Intellectual stimulation & 4 & 0.70 \\
Idealized influence attributed & 4 & 0.80 \\
Contingent reward & 4 & 0.76 \\
Management by exception active & 4 & 0.74 \\
Management by exception passive & 4 & 0.78 \\
Affective commitment & 5 & 0.86 \\
\hline
\end{tabular}

Table 1 shows that Cronbach's alpha for all constructs was 0.70 and above, therefore the research instrument used in this study was reliable and consistent.

Correlations between leadership style behaviours and affective commitment

Table 2 shows the results on four transformational leadership behaviours and their relationship to subordinate affective commitment to the organisation. There was a weak positive correlation between idealised influence, individual consideration to affective commitment; significant at $(\mathrm{r}=0.109 ; p<0.05)$ and at $(\mathrm{r}=$ $0.22 ; p<0.05$ ), respectively. Inspirational motivation had a moderate positive correlation with affective commitment significant at $(\mathrm{r}=0.46 ; p<0.05)$ and Intellectual stimulation was found to have a strong correlation with affective commitment, significant at $(\mathrm{r}=0.67 ; p<0.05)$.

The results as displayed in Table 2 show that charismatic and inspirational leadership style has moderate to strong positive relationship with subordinate affective commitment to the organisation.

Table 3 shows the results on transactional leadership behaviours and how they relate to subordinate affective commitment. It was found that contingent reward behaviours had a moderate positive correlation between subordinate 
Table 2. Transformational leadership style and affective commitment.

\begin{tabular}{clc}
\hline & & AFFECTIVE COMMITMENT \\
\hline IDEALISED_INFLUENCE & Pearson Correlation & $0.109^{* *}$ \\
& Sig. (2-tailed) & 0.000 \\
& $\mathrm{~N}$ & 113 \\
INSPIRATIONAL_MOTIVATION & Pearson Correlation & $0.461^{* *}$ \\
& Sig. (2-tailed) & 0.000 \\
& $\mathrm{~N}$ & 113 \\
INTELLECTUAL_STIMULATION & Pearson Correlation & $0.671^{* *}$ \\
& Sig. (2-tailed) & 0.000 \\
INDIVIDUAL_ & $\mathrm{N}$ & 113 \\
CONSIDERATION & Pearson Correlation & $0.22^{* *}$ \\
& Sig. (2-tailed) & 0.000 \\
& $\mathrm{~N}$ & 113 \\
\hline
\end{tabular}

Source: research data output from SPSS version 23.

Table 3. Transactional leadership style and affective commitment.

\begin{tabular}{|c|c|c|}
\hline & & AFFECTIVE COMMITMENT \\
\hline \multirow{3}{*}{ CONTINGENT_REWARD } & Pearson Correlation & $0.421^{* *}$ \\
\hline & Sig. (2-tailed) & 0.000 \\
\hline & $\mathrm{N}$ & 113 \\
\hline \multirow{3}{*}{$\begin{array}{c}\text { MANAGEMENT_BY_EXCEPTION_ } \\
\text { ACTIVE }\end{array}$} & Pearson Correlation & $-0.012^{* *}$ \\
\hline & Sig. (2-tailed) & 0.000 \\
\hline & $\mathrm{N}$ & 113 \\
\hline \multirow{3}{*}{$\begin{array}{c}\text { MANAGEMENT_BY_EXCEPTION_ } \\
\text { PASSIVE }\end{array}$} & Pearson Correlation & $-0.346^{* *}$ \\
\hline & Sig. (2-tailed) & 0.000 \\
\hline & $\mathrm{N}$ & 113 \\
\hline
\end{tabular}

Source: research data output from SPSS.

affective commitment to the organisation, significant at $(\mathrm{r}=0.421 ; p<0.05)$. There was a very weak negative correlation between management by exception active with affective commitment, significant at $(\mathrm{r}=-0.012 ; p<0.05)$, and a moderate negative correlation between management by exception passive and subordinate affective commitment, significant at $(\mathrm{r}=0.346 ; p<0.05)$.

\section{Conclusion}

This study concludes that employees intrinsically motivated employees are willing to stay at their places of work for longer periods as they will be job satisfied. Employees generally prefer to be treated as valuable assets of an organisation hence managers ought to employ benign supervision when managing employ- 
ees. The managers should guard against being autocratic when managing employees as this will demoralise employees. It can also be affirmed that employees can also be motivated by having clear goals which are measurable and above all not ambiguous which gives clear definition as to the expectations of the objective. In addition, employees are often motivated by the anticipated significance upon successful completion of the particular task. Furthermore, there is a direct correlation between employee motivation to complete an objective and their involvement in establishing the goal and its boundaries. The managers should consistently provide clarity of expectations, ability to adjust difficulty, and the opportunity to gain recognition to employees so as to motivate them.

\section{Recommendations}

This study recommends that employees in the mineral sector in Zimbabwe should involve employees in decision-making through the use of the democratic leadership style so as to raise the standards of efficiency and effectiveness of an organization and lastly foster an environment in which there are good industrial relations through effective communication. The democratic leadership style engenders semi-autonomous group work and teamwork as both are forms of on-line direct participation of shop-floor workers in work-related decisions.

Managers of mining companies should develop effective ways and techniques for managing change through the democratic leadership style. Employees can be changed through sensitivity training that is changing people's behaviour through unstructured group interaction, survey feedback, team building, inter-group development and process consultation. Managers should therefore use the appropriate leadership style in order to cope with change.

The management of mining firms in Zimbabwe ought to develop its employees so as to raise the standards of efficiency and effectiveness of an organization. Development of employees is crucial because it contributes towards the achievement of an organisation's objectives. It can also be observed that development is concerned more with changes in attitude, behaviour and employee potential than with immediate skill. It can also be noted that through the acquisition of new knowledge and job skills, employees increase their market value and earning power.

The managers should create a conducive environment where employees can air their grievances openly and freely without fear of victimization. Employees feel accommodated if they perceive the environment in which they are to be conducive. A model environment is one in which employees can initiate action and above all there are clear channels of communication. The democratic leadership style becomes the panacea in this regard.

\section{Further Research}

Considering the fact that this is the first research on the effect of leadership style on employee commitment in the mining sector in zimbabwe. It will be prudent 
to amass a lot of data for instance by investigating the same aspect in a number of mineral sectors such as gold, platinum and chrome among others so as to have an in-depth understanding of these constructs holistically. A study into the effect of the indigenization policy on employee morale in the Zimbabwean diamond mining sector is recommended.

\section{Conflicts of Interest}

The authors declare no conflicts of interest regarding the publication of this paper.

\section{References}

Armstrong, M. (2006). A Handbook of Human Resource Management Practice. Kogan Page.

Bass, B. (1985). Leadership and Performance Beyond Expectations. New York: Free Press.

Bass, B., \& Avolio, B. J. (1997). Concepts of Leadership in Vecchio (2007) Leadership: Understanding the Dynamics of Power and Influence in Organizations. University of Notre Dame Press. https://doi.org/10.2307/j.ctvpg85tk.6

Brotheridge, C. M., Lee, R. T., Ozcelik, H., Langton, N., \& Aldrich, H. (2008). Doing Well and Doing Good: The Relationship between Leadership Practices That Facilitate a Positive Emotional Climate and Organizational Performance. Journal of Managerial Psychology, 23, 186-203. https://doi.org/10.1108/02683940810850817

Burns, J. M. (1978). Leadership. New York: Harper \& Row.

Chamber of Mines of Zimbabwe (CMZ) (2013). Overview of Zimbabwe's Mining. Government of Zimbabwe.

Chamber of Mines of Zimbabwe (CMZ) (2015). State of the Mining Industry Survey Report. Government of Zimbabwe.

Chamber of Mines of Zimbabwe (CMZ) (2016). Contribution of the Mining Sector to Sustainable Economic Development of the Zimbabwean Economy.

Chamber of Mines of Zimbabwe (CMZ) (2017). 2017-State of the Mining Industry Survey Report. Republic of Zimbabwe.

Chamber of Mines of Zimbabwe (CMZ) (2018). State of the Mining Industry 2018 Report Prospects.

Creswell, J. W. (2013). Qualitative Inquiry \& Research Design Choosing among Five Approaches (3rd ed., p. 42). SAGE.

Edmonds, W. A., \& Kennedy, T. D. (2012). An Applied Reference Guide to Research Designs: Quantitative, Qualitative, and Mixed Methods. Sage.

Emery, C. R., \& Bakker, K. J. (2007). The Effect of Transactional and Transformational Leadership Styles on the Organizational Commitment and Job Satisfaction of Customer Contact Personnel. Journal of Organizational Culture, Communication and Conflict, 1191, 77-90.

Hair, J. F., Sarstedt, M., Hopkins, L., \& Kuppelwiesser, V. G. (2014). Partial Least Squares Structural Equation Modeling (PLS-SEM): An Emerging Tool in Business Research. European Business Review, 26, 106-121. https://doi.org/10.1108/EBR-10-2013-0128

Hayward, Q., Gloss, M., \& Tolmay, R. (2004). The Relationship between Transformational and Transactional Leadership and Employee Commitment. Rhodes Univertisty Business. 
Hazriyanto, H., \& Ibrahim, B (2019). The Factor Analysis of Organizational Commitment, Job Satisfaction and Performance among Lecturers in Batam. Journal of Technical Education and Training, 11, 151-158. https://doi.org/10.30880/jtet.2019.11.01.019

Horwitz, F. M., \& Budhwar, P. (Eds.) (2016). Handbook of Human Resource Management in Emerging Markets. Edward Elgar Publishing. https://doi.org/10.4337/9781781955017

Krejcie, R. V., \& Morgaon, D. W. (1970). Determining Sample Size for Research Activities. Education and Psychological Measurement, 30, 607-610. https://doi.org/10.1177\%2F001316447003000308

Kshirsagar, M., \& Waghale, V. Y. (2014). Impact of Financial and Nonfinancial Rewards on Employee Motivation. International Research Journal of Management and Commerce, 1, 61-74.

Lahkar Das, B., \& Baruah, M. (2013). Employee Retention: A Review of Literature. IOSR Journal of Business and Management (IOSR-JBM), 14, 8-16. https://www.iosrjournals.org

Lee, J. (2005). Effects of Leadership and Leader-Member Exchange on Commitment. Leadership \& Organization Development, 26, 655-672. https://doi.org/10.1108/01437730510633728

Marshal, C., \& Rossman, G. (2016). Designing Qualitative Research (6th ed.). University of North Carolina.

Meyer, J. P., \& Allen, N. J. (2004). TCM Employee Commitment Survey. Academic Users' Guide 2004. Department of Psychology, University of Western Ontario.

Meyer, J. P., \& Allen, N. J. (2007). Model of Organizational Commitment: Measurement Issues. The Journal of Organizational Behaviour, 6, 7-25.

Nyengane, M. H. (2007). The Relationship between Leadership Style and Employee Commitment: An Exploratory Study in an Electricity Utility of South Africa. Dissertation, Rhodes University.

Robbins, S. P., \& Coulter, M. (2012). Management (11th ed.). Prentice Hall.

Robbins, S. P., Judge, T. A., Odendaal, A., \& Roodt, G. (2010). Organisational Behaviour: Global and South African Perspective (2nd ed.). Pearson Education.

Segula, S. (2015). Contribution of the Mining Sector to Sustainable Economic Development of the Zimbabwean Economy. Chairman-Platinum Producers Association's Report, Zimbabwe Chamber of Mines.

Steyrer, J., Schffinger, M., \& Lang, R. (2008). Organisational Commitment-A Missing Link between Leadership Behaviour and Organisational Performance? Scandinavian Journal of Management, 24, 364-374. https://doi.org/10.1016/j.scaman.2008.04.002

World Bank (2009). Protecting Progress. The Challenge Facing Low Income Countries in the Global Recession. World Bank.

York, J. (2017). Behavior in Organizations. Lectures in Pensacola, Florida, 2-9 March 2017. 